\title{
Carcass yield characteristics of normal feathered indigenous Malawian chickens
}

\begin{abstract}
An evaluation study on carcass yield characteristics of normal feathered indigenous chickens was carried out at Bunda Campus of the Lilongwe University of Agriculture and Natural Resource (LUANAR). The study involved seventy-one (71) normal feathered IC which were selected at the same age of 6 weeks. Twenty-three normal feathered IC were under intensive system supplemented with balanced ration and 48 normal feathered IC were under free range system supplemented with maize bran. Six (6) chickens (3 hens and 3 cocks) were selected randomly and slaughtered at 20, 24, and 28 weeks of age from each system. The feeding period was seven months. The results showed that sex, age and management system significantly $(\mathrm{P}<0.05)$ affect carcass yield. The results also showed that chickens reared under intensive system had higher carcass weights compared to those under free range system. Cocks had significantly $(\mathrm{P}<0.05$ higher carcass yields in all traits measured compared to hens of the same age. It is therefore, concluded that normal feathered IC reared under intensive system should be slaughtered at the age of 20 weeks and those under free range system should be slaughtered at the age of 24 weeks where higher carcass yields were obtained. In conclusion, sex, age and management system affected carcass yield characteristics of Malawian normal feathered IC.
\end{abstract}

Keywords: carcass, indigenous chicken, malawi
Volume 2 Issue 6 - 2017

Chimwemwe Chigoma, Jonathan Tanganyika Animal Science Department, Lilongwe University of Agriculture and Natural Resources, Malawi

\begin{abstract}
Correspondence: Jonathan Tanganyika, Animal Science Department, Bunda campus, Lilongwe University of Agriculture and Natural Resources (LUANAR), PO Box 219, Lilongwe, Malawi,Tel 265-993 494 774, Email jtanganyika@gmail.com
\end{abstract}

Received: July 12, 2017 | Published: December 29, 2017

\section{Introduction}

Indigenous chickens are important for nutrition and income security among the poor rural households and are the most widely kept livestock species in the world. ${ }^{1}$ In Malawi, poultry is the most dominant species and more than $80 \%$ of the national poultry population is kept in the rural areas. ${ }^{2}$ There are various phenotypes of indigenous chickens among which are; normal feathered chickens, naked neck, frizzled, dwarfs and others. According to, ${ }^{2}$ the phenotypic names of indigenous chickens are descriptive, based on feather plumage, legs, tail feathers, head, and other features like colour. Among the many genotypes of indigenous chickens, normal feathered ICs are common and found in most households in Malawi. Literature from elsewhere has shown that age of indigenous chickens at slaughter affects the flavor of meat ${ }^{3}$ while sex also affects live body weight, blood yield and feather yield in chickens. ${ }^{4}$ However, in Malawi, there is no literature for carcass yield characteristics of normal feathered indigenous Malawian chickens. This has led to slaughter and selling of normal feathered indigenous chickens without considering carcass yield and composition. Therefore, this study seeks to determine the effect of sex, age at slaughter and management systems on carcass yield of normal feathered indigenous Malawian chickens.

\section{Materials and methods}

\section{Study area}

This study was conducted at Students farm, Bunda campus of Lilongwe University of Agriculture and Natural Resources (LUANAR). The study used normal feathered chickens which were under Indigenous Chicken Improvement Program (InCIP). The study was run for seven months from August 2013 to February 2014.

\section{Management of experimental animals}

Seventy one normal feathered indigenous chickens were used in this study, where 48 normal feathered indigenous chickens were reared under free range system supplemented with maize bran only in the morning before going for scavenging and 23 normal feathered indigenous chickens were reared under intensive management system, where a ration containing $17 \%$ crude protein $(\mathrm{CP})$ was given to the experimental chickens from the start of the trial to the end. The experiment used pullets of the same age (6 weeks). At the end of the experiment, six normal feathered indigenous chickens $(3$ hens and 3 cocks) were selected randomly and slaughtered at the age of 20,24, and 28 weeks of age from each system.

\section{Data collection}

Before slaughter, the chickens were starved for 12 hours and slaughtering was done after stunning the birds using the pointed part of the knife by piercing it on the medulla oblongata of the chicken. After severing the neck, the birds were scalded using hot water. They were defeathered, eviscerated and washed to remove any splashes of intestinal contents on the carcass. The data collected included; age of the bird, initial weight, live weight, Weight of gizzards, intestines, thighs, heads, breast muscles, feathers, wings, blood, liver, necks, shanks, hot dressed and thigh circumferences.

\section{Data analysis}

The data collected was subjected to General Linear Model (GLM) of the Statistical Packages for Social Science (SPSS) package considering effects of management, sex and age at slaughter as treatments. Turkey's test, descriptive statistics, estimated means were used to compare the means at the level of significance of $\mathrm{P}<0.05$. 


\section{Statistical model}

$Y_{i j k l}=\mu+M_{i}+A_{j}+S_{k}+(M A)_{i k}+(M S)_{j k+}(M A S)_{i j k}+e_{i j k l}$

Where $Y_{i j k l}=$ Observed carcass yield characteristics traits

$\boldsymbol{\mu}=$ Overall mean of the observation

$M_{i}=$ Effect of the $i^{\text {th }}$ management (i=1; free range, 2 ; intensive) weeks)

$A_{j}=$ Effect of the $i^{t h}$ age $(\mathrm{j}=1 ; 20$ weeks, 2;24 weeks, 3;28

$S_{k}=$ Effect of the $k^{\text {th }}$ sex (k=1; cocks, 2 ; hens)

$(M A)_{i j}=$ Interaction effect of the $i^{t h}$ management and the $i^{t h}$

$(M S)_{i k}=$ Interaction effect of the $i^{t h}$ management and the $k^{\text {th }}$ $\operatorname{sex}$

$(M A S)_{i j k}=$ Interaction effect of the $i^{\text {th }}$ management, $j^{\text {th }}$ age and $k^{\text {th }}$ sex $e_{i j k l}=$ Random error component

\section{Results}

Effect of sex, age and management system on carcass characteristics in indigenous normal Malawian chickens were significant $(\mathrm{P}<0.05)$ as summarised in (Table 1). Sex significantly $(\mathrm{P}<0.05)$ affected all the parameters measured with cocks showing remarkable and better carcass yield than hens for all the traits measured. The current results also found that age significantly $(\mathrm{P}<0.05)$ affected all the carcass traits measured of the normal feathered indigenous chickens at the same age in three age groups. There was a decrease in weight when the chickens were growing which could be due to sexual activities and reproduction that took place that used much of their energy instead of body maintenance and growth. On the other hand, growth performance of normal feathered indigenous chickens reared under intensive management system was better that free range system. Interaction between sex, age and management systems was tested and was not significant (Table 1).

Table I Effect of sex, age and management system on carcass yield characteristics (Mean \pm SE)

\begin{tabular}{|c|c|c|c|c|c|c|c|c|c|c|}
\hline \multirow[b]{2}{*}{$\begin{array}{l}\text { Dependent } \\
\text { Variable (G) }\end{array}$} & \multicolumn{3}{|l|}{ Sex } & \multicolumn{4}{|l|}{ Age } & \multicolumn{3}{|c|}{ Management System } \\
\hline & Cocks & Hens & Sig. & $\begin{array}{l}20 \text { Weeks } \\
\text { (G) }\end{array}$ & $\begin{array}{l}24 \text { Weeks } \\
\text { (G) }\end{array}$ & $\begin{array}{l}28 \text { Weeks } \\
\text { (G) }\end{array}$ & Sig. & $\begin{array}{l}\text { Free } \\
\text { Range }\end{array}$ & Intensive & Sig. \\
\hline Live weight & $\begin{array}{l}1103.17 \\
\pm 42.13\end{array}$ & $\begin{array}{l}956.99 \\
\pm 42.13\end{array}$ & $*$ & $\begin{array}{l}920.08 \\
\pm 52.19\end{array}$ & $\begin{array}{l}1036.58 \\
\pm 52.19\end{array}$ & $\begin{array}{l}983.42 \\
\pm 52.19\end{array}$ & $*$ & $\begin{array}{l}874.44 \\
\pm 42.61\end{array}$ & $\begin{array}{l}1085.60 \\
\pm 42.6 \mathrm{I}\end{array}$ & $*$ \\
\hline Thigh weight & $122.59 \pm 5.74$ & $93.81 \pm 5.74$ & $*$ & $\begin{array}{l}102.82 \\
\pm 7.04\end{array}$ & $\begin{array}{l}109.13 \\
\pm 7.04\end{array}$ & $\begin{array}{l}112.65 \\
\pm 7.04\end{array}$ & $*$ & $88.98 \pm 5.74$ & $\begin{array}{l}127.42 \\
\pm 5.74\end{array}$ & $* *$ \\
\hline $\begin{array}{l}\text { Hot carcass } \\
\text { weight }\end{array}$ & $\begin{array}{l}782.85 \\
\pm 31.26\end{array}$ & $\begin{array}{l}608.12 \\
\pm 31.26\end{array}$ & * & $\begin{array}{l}599.77 \\
\pm 38.29\end{array}$ & $\begin{array}{l}737.23 \\
\pm 38.29\end{array}$ & $\begin{array}{l}749.45 \\
\pm 38.29\end{array}$ & $*$ & $86.19 \pm 5.32$ & $\begin{array}{l}110.29 \\
\pm 5.32\end{array}$ & $*$ \\
\hline $\begin{array}{l}\text { Drum stick } \\
\text { weight }\end{array}$ & $|15.0| \pm 5.32$ & $81 \pm 5.32$ & $* *$ & $90.29 \pm 6.51$ & $\begin{array}{l}100.51 \\
\pm 6.51\end{array}$ & $\begin{array}{l}103.91 \\
\pm 6.51\end{array}$ & * & $\begin{array}{l}\mid 29.91 \\
\pm 8.23\end{array}$ & $\begin{array}{l}191.28 \\
\pm 8.23\end{array}$ & $* *$ \\
\hline $\begin{array}{l}\text { Breast muscle } \\
\text { weight }\end{array}$ & $178.65 \pm 8.23$ & $\begin{array}{l}142.53 \\
\pm 8.23\end{array}$ & * & $\begin{array}{l}150.26 \\
\pm 10.08\end{array}$ & $\begin{array}{l}158.26 \\
\pm 10.08\end{array}$ & $\begin{array}{l}173.29 \\
\pm 10.08\end{array}$ & $*$ & $72.17 \pm 2.50$ & $90.65 \pm 2.50$ & $* *$ \\
\hline Weight of wings & $91.26 \pm 2.46$ & $71.56 \pm 2.46$ & $*$ & $77.62 \pm 3.03$ & $\begin{array}{l}78.58 \\
\pm 3.03\end{array}$ & $88.02 \pm 3.03$ & $*$ & $36.98 \pm 2.47$ & $\begin{array}{l}48.04 \pm \\
2.47\end{array}$ & $*$ \\
\hline Weight of necks & $48.61 \pm 2.47$ & $36.51 \pm 2.47$ & $*$ & $39.09 \pm 3.03$ & $\begin{array}{l}46.26 \\
\pm 3.03\end{array}$ & $42.26 \pm 3.03$ & $*$ & $\begin{array}{l}608.64 \\
\pm 31.26\end{array}$ & $\begin{array}{l}782.33 \\
\pm 31.26\end{array}$ & * \\
\hline
\end{tabular}

**:Very Significant, *: Significant

\section{Discussion}

The findings in the current study on effect of sex are in agreement with the report by ${ }^{5}$ who reported that normal feathered indigenous chicken cocks have higher proportion of total carcass. This is due to sexual dimorphism which is the phenotypic difference between males and females of the same species such as differences in size and body structures between sexes at slaughter and carcass yield of the chicken. Sexual dimorphism has been revealed by several reports to usually favour males compared to females especially in poultry. ${ }^{6,7}$ The existing sexual dimorphism is explained by the differences in levels of male sex hormone which is responsible for greater muscle development in males than in females. ${ }^{8}$ attributed this difference of sex which arises from the male physiological activities. It has also been reported that differences in growth between sexes are usually due to differences in hormonal profile, aggressiveness and dominance especially when both sexes are reared together. ${ }^{6}$ According to, ${ }^{9}$ aggressiveness of males over the females especially when reared together put the females at a disadvantage for feed and water. ${ }^{4}$ Also reported that growth and carcass differences between cocks and hens are due to differences in feed metabolism and in the onset of fattening.

Results on effect of age at slaughter show that the appropriate age to yield higher live weight was at the age of 24 weeks with mean weight of $1.1 \mathrm{~kg}$ when compared to 20 and 28 weeks. According to, ${ }^{3}$ the ages affect the taste and tenderness of the meat, especially taste and flavour. The more time the chickens are kept, taste will be improved but tenderness decreases. However, the current results are contrary to the findings ${ }^{10}$ who stated that the appropriate age for normal feathered indigenous chickens to possess economical live weight was in the range of 16-18 weeks of age while Thai normal feathered indigenous chicken shows an appropriate age for consumption between 16-20 weeks, with $1.2-1.5 \mathrm{~kg}$ live weight. The variation could be due to the differences in environmental factors since Malawi is under tropical 
regions with high temperatures which leads to low feed intake and reduces the weight of chickens during slaughter. Another reason could be different genotypes used.

On management systems, the current study found that chickens reared under the free range system exhibited the lowest body weight gain $(\mathrm{P}<0.05)$, while those kept under intensive system attained more weight gains. These findings are similar to ${ }^{11}$ in Uganda. Intensive production systems are associated with temperature, photoperiod and light intensity controlled conditions, high energy diets, high plane of nutrition and high feed conversion efficiency which encourage rapid growth of the chickens. ${ }^{12}$ However, chickens on free range may be faced with a number of varying factors such as feed quality and quantity, ${ }^{13}$ temperature, photoperiod and light intensity. ${ }^{14}$ In addition, ${ }^{15}$ reported a higher locomotor activity in chickens with free range system. According to ${ }^{16}$ chickens on free range system can scavenge across large areas. The increased kinetic activity together with the uncontrolled environmental conditions could increase energy expenditure, ultimately affecting their carcass yield. Therefore, the chickens reared under intensive production system grow faster and produce heavier slaughter weight and carcass yield with more fat than free range chickens. ${ }^{17}$ The results also coincide with findings by ${ }^{18}$ who reported lower growth rates and carcass weights in free range chickens compared to intensively managed chickens.

\section{Conclusion}

Carcass yield characteristics are affected by sex, age and management system. It was revealed in this study that normal feathered indigenous Malawian cocks showed highest mean values and superiority over hens in almost all the carcass traits under study. The normal feathered indigenous chickens reared under intensive system had higher carcass yield at the age of 20 weeks while those reared under free range had higher carcass yield at the age of 24 weeks with mean live weights of $1.1 \mathrm{~kg}$ and $0.9 \mathrm{~kg}$ respectively. Chickens reared under intensive system showed superior carcass weights compared to those reared under free range system. In addition, carcass yield characteristics showed a marked significant $(\mathrm{P}<0.05)$ differences between cocks and hens where cocks dominate in all the parameters measured in the study compared to hens. It is therefore, recommended that normal feathered indigenous Malawian chickens should be supplemented with concentrates so that during slaughter period higher carcass yields can be obtained. Further studies should be done to evaluate the meat quality of normal feathered indigenous chickens reared under intensive and free range systems, starting from the same age and slaughtered at the age of 20,24 and 28 weeks with equal number of sex slaughtered at each age.

\section{Acknowledgements}

Many thanks to Indigenous Chicken Improvement Programme (InCIP) for funding the research part of this project which was conducted as partial fulfillment of the requirement of Bachelors degree in Animal Science, 2013/14 academic year. Special thanks to my Supervisor, Mr. Jonathan Tanganyika for his advice and encouragement during the whole period of research. The entire team of InCIP led by Prof. T.N. Gondwe deserves many thanks. Special mention to Dr W Jere for his guidance on experimental design and data analysis. Finally, many thanks to Mr Chidzala, Mr Thom, Ms Mtisunge and all members of staff, Animal Science Department at LUANAR for their support in one way or the other.

\section{Conflict of interest}

The author declares no conflict of interest.

\section{References}

1. Perry BD, Randolf TF, Mcdermott JJ, et al. Investing in Animal Health research to alleviate poverty. 2002.

2. Gondwe TNP, Wolny CBA, Safalaoh ACL, et al. Community-Based Promotion of Rural Poultry Diversity, Management. Malawi: Utilization and Research in Malawi; 2003. p. 69-76.

3. Jaturasitha S. Meat Management. Thailand: Mingmuang Press; 2004.

4. Musa HH, Chen GH, Cheng JH, et al. Study on carcass characteristics of chicken breeds raised under the intensive condition. International Journal of Poultry Science. 2006;5(6):530-533.

5. Theerachai H. Study on chicken meat production for small-scale Farmers in North east Thailand. 2006.

6. Ilori BM, Peters SO, Ikeobi CON, et al. Comparative Assessment of Growth in Pure and Crossbred Turkeys in a Humid Tropical Environment. International Journal of Poultry Science. 2010;9(4):368-375.

7. Peters SO, Ikeobi CON, Ozoje MO, et al. Genetic variations in the performance of the Nigeria local chicken. Tropical of Animal Production Investigation. 2002;5:37-46.

8. Fayeye TR, Ayarinde KL, Ojo V, et al. Frequency and influence of some major genes on body weight and body size parameters of Nigeria chickens. Livestock Research for Rural Development. 2006:18(3).

9. Adedeji TA, Adebambo OA, Ozoje MO, et al. Early growth performance of crossbred chickens resulting from different sire strains. 2004.

10. Watanachant C, Watanasit S, Watanachant S, et al. Carcass Characteristics, physical property and chemical composition of naked-neck and Thai indigenous chickens reared under backyard production systems. 2007.

11. Magala H. Effect of Management System on the Performance of Growing Local Chicken Cockerels. Uganda: A special Project Report Submitted to Faculty of Agriculture Makerere University; 2008. p. 25-34.

12. Lawrie RA, Ledward DA. Lawries Meat Science. 7th ed. Journal of Cell Animal Biology. 2006;2:63-71.

13. Kingori AM, Wachira AM, Tuitoek JK. Indigenous Chicken Production in Kenya: A Review. International Journal of Poultry Science. 2010;9(4):309-316.

14. Wang KH, Shi SR, Dou TC, et al. Effect of a free-raising system on growth performance, carcass yield, and meat quality of slow-growing chicken. Journal of Poultry Science. 2009;88(10):2219-2223.

15. Ponte PIP, Rosado CMC, Crespo JP, et al. Pasture Intake Improves Performance and Meat Sensory Attributes of Free-Range Broilers. Poultry Science. 2008;87(1):71-79.

16. Dal Bosco A, Mugnai C, Sirri F, et al. Assessment of a Global Positioning System to Evaluate Activities of Organic Chickens at suture. Journal Applied to Poultry Resources. 2010;19:213-218.

17. Fanatico AC, Pillai PB, Hester PY, et al. Performance, Livability, and Carcass Yield of Slow- and Fast-Growing Chicken Genotypes Fed Low-Nutrient or Standard Diets and Raised Indoors or With Outdoor Access. Poultry Science. 2005;87(6):1012-1021.

18. Castellini C, Mugnai C, Dal Bosco A. Meat Quality of Three Chicken Genotypes Reared According to the Organic System. Italian Journal of Food Science. 2002;14(4):401-412. 